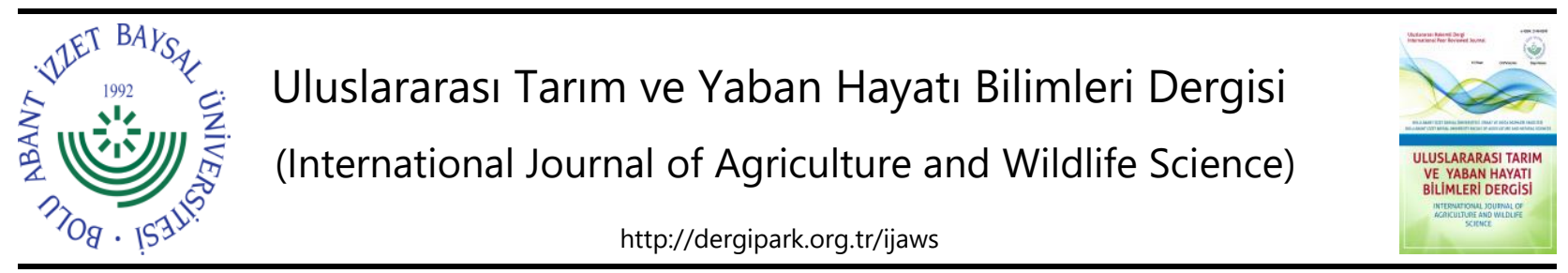

Araştırma Makalesi

\title{
Kırdan Kente Göç Eden Ailelerin Kız Çocuklarına Yönelik Tutum ve Davranışları (Tokat ili Merkez İlçe Araştırması)
}

\author{
Nuray Kızılaslan ${ }^{1^{*}}$ (D) , Eda Solmaz ${ }^{2}$ (D), \\ ${ }^{1}$ Tokat Gaziosmanpaşa Üniversitesi, Ziraat Fakültesi, Tarım Ekonomisi Bölümü, Tokat \\ ${ }^{2}$ Sosyal Güvenlik II Müdürlüğü, Tokat
}

Geliş tarihi (Received): 05.05.2021

Kabul tarihi (Accepted): 04.08.2021

Anahtar kelimeler:

Göç, kır-kent, Tokat ili, kırsal aile, kız çocuk
*Sorumlu yazar

nuray.kizilaslan@gop.edu.tr
Özet. Bu araştırmada kırdan kente göçün göç eden aile bireyleri üzerindeki etkileri, ekonomik ve sosyal yaşamlarındaki değişimler incelenmiştir. Araştırma, Tokat merkez ilçede belirlenen 21 mahallede yaşayan kırdan göç etmiş 402 aile üzerinde yürütülmüştür. Araştırmada elde edilen veriler faktör analizi ile değerlendirilmiştir. Araştırmada ailelerin kız çocuklarına yönelik tutum ve davranışlarını ölçmek amacıyla faktör analizi yapılmıştır. Analizde özdeğerleri 1'den büyük olan faktör sayısı 5 olup, bu faktörler toplam varyansın \%63.633'ünü açıklamaktadır. Genel olarak ailelerin kız çocuklarının eğitimleri, çalışmaları ve evlilikleri konusunda olumlu tutum içinde oldukları sonucu ortaya çıkmıştır. Ayrıca, kırdan kente göç eden ailelerin kız çocuklarına yönelik geleneksel düşüncelerden arındığı, onların okumaları ve çalışmalarını önemsediği, kız ve erkek çocukları arasında ayrım yapmak istemedikleri, cinsiyet eşitsizliğine karşı oldukları sonucu ortaya çıkmaktadır. Kız çocuklarının güçlendirilmesine yönelik faaliyetlerin sürdürülmesi gerekmektedir.

\section{Attitudes and Behaviours Toward Daughters of Families That Have Immigrated from Rural to Urban (Tokat Province Central District Research)}

\section{Keywords:}

Migration, rural-urban, Tokat province, rural family, daughters

\footnotetext{
Abstract. In this research was examined effects of migration on migratory family members and changes in their economic and social lives. The research was conducted rural families living in 21 neighborhoods on 402 in the central district of Tokat. The data obtained in the study were evaluated by factor analysis. Factor analysis was conducted to measure the attitudes and behaviors of families towards girls. In the analysis, the number of factors with eigenvalues greater than 1 is 5 and these factors explain $63.633 \%$ of the total variance. In general, it has been concluded that families have positive attitudes towards the education, work and marriage of girls. In addition, it is revealed that families migrating from rural to urban are cleansed of traditional thoughts about girls, care about their education and studies, do not want to differentiate between boys and girls, and are against gender inequality. Activities aimed at empowering daughters need to be continued.
} 


\section{GiRiş}

Toplumlarda süresi ve nedenine bakılmaksızın bireylerin yer değiştirmesi sonucunu meydana getiren nüfus hareketleri göç olgusudur. Bu yer değiştirme hareketleri çeşitli faktörlerden dolayı gönüllü veya zorunlu nedenlerle gerçekleşebilmektedir.

Sosyal bilimler bakımından "insanın coğrafi hareketliliği ve bu hareketliliğin sebep olduğu nüfus dinamiği" olarak da açıklanan göç; sebep ve sonuçları açısından çeşitlilik arz eden ve birçok sosyal, ekonomik ve demografik değişimi ortaya çıkarmaktadır (Pala, 2013). Günümüzde dünyada yer alan yoksul ülkelerin sosyo-ekonomik özelliklerinin iyileştirilmesinin yanında sağlık koşullarının da iyileştirilmesine yönelik çalışmalar gündemini korumaktadır (Kızılaslan, 2016).

Birey ve toplum açısından göç, mekânsal bir değişiklik olmasının yanı sıra, birey ve toplumun değerlerinde değişim ve dönüşüme neden olmaktadır. Bu değişim ve dönüşüm bireyleri sosyal, ekonomik ve kültürel olarak etkilemektedir (Ekici ve Tuncel, 2015).

Türkiye'de sanayileşme akımının 1950'li yıllardan sonra hız kazanmaya başlaması iller arasında göçün ortaya çıkmasına neden olmuştur. Nüfus hareketleri gelişmemiş bölgelerden gelişmiş bölgelere doğru başlamış ve ülke iç göç kavramıyla tanışmıştır.

Göçler ülkelerin ya da küçük toplulukların nüfusunun artışına veya azalmasına etki eden önemli etmenlerden birisidir. Ayrıca nüfusun yaş ve cinsiyet açısından değişmesine de neden olmaktadır. Ortaya çıkan bu değişimler toplumun yapısını, kültürünü, ekonomi, politika vb. bütün faktörlerini kısa sürede etkilemektedir (Karakuş, 2006). Göç süreciyle beraber yeni bir toplumsal çevre oluşmakta, göç edilen yerde uyum sorunları ortaya çıkmaktadır.

Kırdan kente göçü tetikleyen köyün itici güçleri, kentin çekici güçleri ve iletici güçler bulunmaktadır. GSYiH'da tarımın aldığı payın düşmesi, toprak-nüfus baskısı, arazi parçalanması, makinalaşma köyün itici güçlerinden en önemlileridir. Kentte yaşam standartlarının yüksek olması, eğitim, sağlık gibi kaynaklara erişim kolaylığı, sosyal güvence, iş olanaklarının fazla olması kentin çekici gü çleridir. Ulaşım ve haberleşme imkanlarının artış göstermesi ise iletici güç olarak kırdan kente göçü tetiklemiştir.

Kentleşme, sanayileşme ve iktisadi gelişmeye bağı kent sayısının artışı ile kentlerin büyümesini, toplumda artan örgütleşme, uzmanlaşma ve kişilerarası ilişkilerde kentlere özel değişikliklere yol açan nüfus birikim süreci olarak adlandırımaktadır. Kentleşmenin temel sebebi, daha iyi bir yaşam ümididir (Şahin, 2010).

Kentler toplum hayatını ilk dönemlerden bugüne kadar içinde bulunduğu dönemin özelliğine göre şekillendirmiş ve bugün toplumların kaderini belirleyecek niteliksel düzeye ulaşmıştır. Medeniyetin ve kültürlerin doğup büyüdügü alanlar olarak kentler günümüzde önceki dönemlere oranla önem derecesi, etkileme hızı ve etki alanı artmış esas olgular arasındadır. Böylelikle mutlak bir yerleşim birimi olmanın ötesine geçmiştir (Geyik, 2010).

Kentleşme olgusunun en temel yönlerinden birisi de yeni bir toplumsal değişim ve şekillenme süreci olmasıdır. Kentleşmeyle nüfus, yeni sosyal ilişkiler ve örgütlenmeyle yeni topluluk meydana getirmektedir. Kır topluluklarına ters ve farklı özellikleriyle kent, gruplaşmaların eşitlendiği örgütlü bir birlik ve sistemli bir bütünlük içindedir (Sencer, 1979). Kentleşme toplumsal değişmenin hem nedeni hem de sonucudur ve insanların doğayla, toplumla, hem de birbirleriyle ilişkileri kökten değişmektedir (Erkan, 2010).

Türkiye'de kırdan kente göçün ortaya çıkardığı yığınlaşma sürecini yaşayanlar, kent çevresini hızla kaplayan gecekondu kuşağında oturmakta olup, bir yandan kır özelliklerini kentte yaşamaya çalışan, diğer yandan kent özelliklerine uyum sağlamak zorunda olan, kırla kent arasında sıkışmış, hayatlarında zaman zaman kıra olan özlemi sergileyen yeni alt kültürler meydana getirmiştir. Türk toplumunda tarihten beri her zaman var olan göçlerin pek çok yönleri ile aile içi ilişkileri eşitlikçi yöne yöneltmesi, ailede iş birliği ve iletişimi artırması, kadınların çalışma hayatına girişi ile nispeten özgürleşmesini sağlaması, çocukların daha da değerli hale gelmesi gibi birtakım olumlu yönleri sayılabilir. Olumsuz yönleri ise; ailelerde boşanma oranlarını artırması, kuşaklar arası çatışmaları meydana getirmesi, gençlerin yeteri derecede sosyalleşmemesi ve kendi kültürlerine yabancılaşması, alt kültürler meydana getirmeleri olarak ifade edilmektedir (Arpacı ve Tokyürek, 2008). Kırdan kente göç olayının en önemli sonuçlarından biride göç eden insanların kent hayatına uyum sağlayamamasıdır. Kadınlar kendilerine yüklenen roller ve beklentilerden dolayı kentten yeterli düzeyde faydalanamamaktadır (Kızılaslan ve Kurt, 2017). Kırsal alandan kente göç, kent yaşamına uyum ve zihniyet değişmeleriyle aile yapısında ve aile içi ilişkilerde bazı değişiklikleri beraberinde getirmiştir. Kız çocuklarının öğrenim olanaklarının artması ve aktif çalışma hayatına daha çok katılmalarıyla birlikte, ailedeki geleneksel cinsiyete dayalı iş bölümü kuralları, işgücü piyasasında ve çalışma yaşamında etkisini hala göstermektedir (Arpacı ve Tokyürek, 2008). Geleneksel aile yapısının kadınların 
hayatı üzerinde doğrudan bir etkisi olduğu kadar onların kaynakları, emeği ve geliri kullanma hakkını belirlemede de etkili olmaktadır (Kızılaslan, 2016).

Kırdan kente göç eden ailelerin çocuklarına ilişkin tutum ve davranışları incelenirken kır ve kent arasında kalmış, tezatlık oluşmuş, geleneksel düşünce kalıpları ortada kalmış bir aile yapısıyla karşılaşmak mümkündür. Kız çocuklarının eğitimi, meslek kazanması ve çalışma hayatıyla ilgili olarak birçok sorunla karşı karşıya kalınabilmektedir. Bu durumun sosyal değişimle beraber yavaş da olsa zamanla aşılabileceği söylenebilir.

Yalnızca kır kent farklıı̆ı değil kente uzak ve yakın olan kırsalda dahi tutum ve davranışlar bakımından belli özellikler gösterir. Kente yakın olan köyler kente uzak yaşayanlara göre bazı kentsel davranışlar ve düşünceler bakımından farklıık göstermektedir. Aile şekli, aile genişliği, başlık parası, eğitim, gelir, ulaşım, ürünlerin pazarlanması gibi faktörler uzak köylerin aleyhine gelişmiştir (Kızılaslan, 2006).

Araştırmanın amacl; kırdan kente göç etmiş olan Tokat il merkezinde yaşayan ailelerin kız çocuklarına yönelik tutum ve davranışlarını, kente göçle birlikte gelişen sosyal değişimin aileler üzerindeki etkisini incelemektir. Ayrıca bu çalışmada; ailelerin köyde ve şehirde yaşadıkları süre, nüfus yapısı özellikleri, kız çocuklarına yönelik algıları ile ilgili sorulara cevap aranmıştır. Bununla birlikte kırdan kente göç eden ailelerin yaşam standardının değişmesinde ebeveynlerin kız çocukları üzerindeki rolünün değişiminin incelenmesi amaçlanmıştır. Kırdan kente göç eden ailelerin kız çocuklarının özellikle eğitimi ve meslek kazanması üzerinde geleneksel bir tutumun izlenip izlenmediği ve kentte yaşam süresinin aileler üzerindeki kız çocuklarına tutum ve davranışlarının değişimi araştırılmıştır.

\section{MATERYAL VE METOT}

Araştırma birincil verilere dayanmakta olup anket çalışması yapılmıştır. Anketin güvenirliğini test etmek için cronbach's alpha katsayısı hesaplanmış ve anketin genel güvenirliği 0.708 olarak bulunmuştur.

Araştırmanın evrenini; Tokat ili Merkez İçe kırsal alanı oluşturmaktadır. Kırdan kente göç eden ailelerin yoğun olarak yaşadığı alanlar tespit edilmiştir. Tokat Belediyesi'nden alınan verilere göre (Anonim, 2019) merkez ilçede 42 mahalle bulunmaktadır. 42 mahallenin \%50'si ile çalışılması düşünülmüş 21 mahalle seçilmiştir. Araştırma bölgesi olan 21 mahallenin seçiminde kırdan kente göç etmiş olan ailelerin yoğun olarak yaşadığı ve gecekondu tipi evlerin yaygın olduğu bölgeler olması etkili olmuştur. Bu mahallelerde yaşayan ailelerden tesadüfi olarak seçilmiş olan 402 birey örnek hacmini oluşturmaktadır.

Çizelge 1. Araştırmaya dahil edilen mahalle sayısı ve örneğe giren hane sayısı.

Table 1. The number of neighborhoods included in the study and the number of households included in the sample.

\begin{tabular}{clcll}
\hline \multirow{2}{*}{ Mahalle no } & \multicolumn{1}{c}{ Mahalle adı } & $\begin{array}{c}\text { Hane sayısı } \\
\mathbf{N}_{\mathbf{1}}\end{array}$ & \multicolumn{1}{c}{$\begin{array}{c}\text { Tabaka ağırlığı } \\
\mathbf{N}_{\mathbf{1}} / \mathbf{N}_{\mathbf{N}} \mathbf{a}_{\mathbf{1}}\end{array}$} & \multicolumn{1}{c}{$\begin{array}{c}\text { Örneğe giren hane sayısı } \\
\mathbf{a}_{\mathbf{1}} . \mathbf{n}=\mathbf{n}_{\mathbf{1}}\end{array}$} \\
\hline 1 & Alipaşa & 2483 & $2483 / 28432=0.0873$ & $0.0873 \times 402=35.1071=35$ \\
2 & Büyükbeybağı & 1192 & $1192 / 28432=0.0419$ & $0.0419 \times 402=16.8536=17$ \\
3 & Cami-i Kebir & 334 & $334 / 28432=0.0117$ & $0.0117 \times 402=4.7224=5$ \\
4 & Çay & 1002 & $1002 / 28432=0.0352$ & $0.0352 \times 402=14.1672=14$ \\
5 & Devegörmez & 1346 & $1346 / 28432=0.0473$ & $0.047 \times 402=19.0310=19$ \\
6 & Erenler & 1080 & $1080 / 28432=0.0379$ & $0.037 \times 402=15.2701=15$ \\
7 & Gezirlik & 498 & $498 / 28432=0.0175$ & $0.017 \times 402=7.0412=7$ \\
8 & Gülbaharhatun & 2834 & $2834 / 28432=0.0996$ & $0.099 \times 402=40.0699=40$ \\
9 & Güneşli & 584 & $584 / 28432=0.0205$ & $0.020 \times 402=8.25710=8$ \\
10 & Hocaahmet & 773 & $773 / 28432=0.0271$ & $0.027 \times 402=10.9294=11$ \\
11 & Kabe-i Mescit & 913 & $913 / 28432=0.0321$ & $0.032 \times 402=12.9089=13$ \\
12 & Kaleardı & 758 & $758 / 28432=0.0266$ & $0.0266 \times 402=10.7173=11$ \\
13 & Kemer & 162 & $162 / 28432=0.0056$ & $0.005 \times 402=2.2905=2$ \\
14 & Küçükbeybağı & 660 & $660 / 28432=0.0232$ & $0.023 \times 402=9.3317=9$ \\
15 & Mahmutpaşa & 1940 & $1940 / 28432=0.0682$ & $0.068 \times 402=27.4296=27$ \\
16 & Örtmeliönü & 765 & $765 / 28432=0.0269$ & $0.026 \times 402=10.8163=11$ \\
17 & Perakende & 1120 & $1120 / 28432=0.0393$ & $0.039 \times 402=15.8356=16$ \\
18 & Soğukpınar & 1879 & $1879 / 28432=0.0660$ & $0.066 \times 402=26.5671=27$ \\
19 & Topçubağı & 515 & $515 / 28432=0.0181$ & $0.018 \times 402=7.2815=7$ \\
20 & Yenimahalle & 2538 & $2538 / 28432=0.0892$ & $0.089 \times 402=35.8847=36$ \\
21 & Yeşilımak & 5056 & $5056 / 28432=0.1778$ & $0.177 \times 402=71.4867=72$ \\
\hline Toplam & & $\sum_{N i}=28432$ & & $\Sigma_{\text {ai }=0.999}$ \\
\hline
\end{tabular}


Çizelge 1'de araştırmaya dahil edilen ve örneğe giren hanelerin mahalleler bazında dağılımı verilmiştir.

Elde edilen verilerin analizinde, çok sayıdaki parametre arasında ilişkilere dayanarak verilerin daha da anlamlı ve özet bir biçimde sunulmasını sağlayan çok parametreli bir analiz türü olan faktör analizi kullanıımıştır (Karagöz ve Kösterelioğlu, 2008). Bu yöntemle ailelerin kız çocukları ile ilgili tutum ve davranışlarını gruplandırarak ortak faktörler oluşturmak ve tutum ve davranışlarını daha iyi incelemek amaçlanmıştır. Böylece birçok yargı cümlesini azaltıp basitleştirmek ve daha az değişken oluşturulup Faktör adı olarak isimlendirmek mümkün olmaktadır.

Araştırmada, Tokat ili merkez ilçede yaşayan kırdan kente göç etmiş olan ailelerin kız çocuklarına yönelik tutum ve davranışları Likert tipi ölçekle ölçeklendirilmiştir.

Katılımcılarla ilgili ifadelere "1=Kesinlikle Katılmıyorum, 2=Katılmıyorum, 3=Kararsızım, 4=Katılıyorum, $5=$ Kesinlikle Katılıyorum" olmak üzere cevaplandırmaları istenmiştir.

Araştırmada dikkate alınacak bağımsız değişkenlerin faktör analizine uygunluğunu test etmek amacıyla KaiserMeyer-Olkin (KMO) testi kullanılmıştır. Bunun yanında da Küresellik testi ile de (Barlett Test of Sphericity) anket sonuçlarının faktör analizi uygulamak için uygun olup olmadığı analiz edilmiştir. Test sonuçlarına göre sonuçlar uygun bulunduğu için verilere faktör analizi uygulanmıştır.

\section{BULGULAR VE TARTIŞMA}

Bu araştırma, kırdan kente göç eden ailelerin kız çocuklarına yönelik tutum ve davranışlarını Tokat illi Merkez ilıçe örneğinde tespit etmek amacıyla yapılmıştır.

\section{Ailelerin Göç Süreci ile ilgili Bilgiler}

Insanların ekonomik, sosyal, siyasal, dini veya başka dış etkenler nedeniyle hayatlarının geri kalanını geçirmek üzere yaşadıkları ülkeleri, şehirleri, köyleri, kasabaları vb. yerleşim alanlarını değiştirmeleri şeklinde olan göç (Günay ve ark., 2017) toplumda pek çok değişimi de beraberinde getirmektedir. Bireyler daha iyi bir yaşam standardına kavuşmak için mesleki ve sosyal mobiliteyi artırmaktadır. Göç hem gidilen çevrede hem de bireylerde sosyal ekonomik kültürel farklılaşmaya neden olmaktadır.

Göç; toplumsal, ekonomik, kültürel ve siyasal bir olgu olduğu kadar aynı zamanda bireysel bir süreçtir. Göç edenlerin neden göç ettikleri, nereye gittikleri, gittikleri yerlerde ne kadar kalacakları, giderken hissettikleri ve geride bıraktıklarıyla, gittikleri yer ve orada yaşayacakları, bu yerlere uyum süreçleri, özellikle bireysel açıdan oldukça önemlidir (Kızılaslan, 2013).

Göç, kültürel ve coğrafi şekilde birbirlerinden kopuk kişiler arasında iletişim kurulmasına yol açmaktadır. Bu iletişim davranış şekilleri, değişik fikirler, kültürel unsurlar bakımından kendini göstermektedir. Bu kültürel etkiyi belirleyen en önemli faktör, göç edenlerin göç ettikleri yerlerde yaşayanlarla sosyo-kültürel farkları olup olmadığıdır. Sosyo-kültürel farklıı̆ı̆ belli olduğu durumlarda etkileşim ve uyum zor gerçekleşmektedir. Bu hususta temel belirleyici, toplumsal yapının profilidir (Tümtaş ve Ergun, 2016).

Kırdan kente göç ile birlikte kırsal ailelerin kentlileşme durumu ortaya çıkmaktadır. Kentlileşme, ekonomik ve sosyal niteliği olan bir kavramdır. Ekonomik anlamda kentlileşme, kişinin hayatını tamamen kentte sağlaması, sosyal anlamda kentlileşme ise, kentlere özgü davranış biçimlerini benimsemesidir (Hatipoğlu, 2008).

Kentlileşme, kente özgü toplumsal unsurların yanında fiziksel yapı ve çevre unsurlarıyla bütünleşmenin görüntüsüdür. Kentlileşme ile birlikte aile şeklinin değişerek küçülmesi, akrabalık ilişkilerinin zayıflaması, kadının aile içinde rollerinin değişmesi ve ekonomik olarak bağımsızlığını elde etmesi, tüketim harcamalarının artması gibi tutum ve davranışlarda değişiklikler ortaya çıkmaktadır. Araştırmada öncelikle bireylerin kaç yıl önce göç ettikleri araştııııış ve Çizelge 2 oluşturulmuştur.

Çizelge 2. Göç etme süresi.

Table 2. Immigration period.

\begin{tabular}{lcccccc}
\hline Köyden kente göç etme & \multicolumn{2}{c}{ Kadın } & \multicolumn{2}{c}{ Erkek } & \multicolumn{2}{c}{ Toplam } \\
\cline { 2 - 7 } süresi & $\mathbf{N}$ & $\%$ & $\mathbf{N}$ & $\%$ & $\mathbf{N}$ & $\%$ \\
\hline 0-10 yıl önce & 51 & 27.1 & 90 & 42.1 & 141 & 35.07 \\
11-20 yıll önce & 128 & 68.1 & 81 & 37.8 & 209 & 51.99 \\
21-30 yıl önce & 9 & 4.8 & 43 & 20.1 & 52 & 12.94 \\
Toplam & 188 & 100.00 & 214 & 100.00 & 402 & 100.00 \\
\hline
\end{tabular}


Araştırmaya katılan bireylerden kadınların \%68.1'i 11-20 yıl önce köyden göç etmiş iken, \%27.1'inin 0-10-yıl önce göç ettiği, erkeklerin ise \%42.1'inin 0-10 yıl önce köyden göç etmiş iken, \%37.8'inin 11-20 yıl önce göç ettiği görülmektedir. Ailede erkeğin kentin istihdam imkânlarından yararlanıp ekonomik anlamda ailesine daha iyi hayat sunma arzusu, kadınların köyün zor hayat şartlarından kurtulup hem kendinin hem de çocuklarının daha iyi bir geleceğe sahip olması için kentte yaşama arzusu köyden kente göçü süre anlamında da hızlandırmıştır.

Tokat Ili Merkez İlçesinde kırdan kente göç eden aileler üzerinde yapılan bir çalışmada, bireylerin ilkokul sonrası eğitiminin çok düşük olduğu, köyde arazilerinin ve akrabalarının bulunmasından dolayı köyle ilişkilerinin kesilmediği, en büyük sorunun işsizlik olduğu, çalışanların ise genellikle işçi olduğu bulunmuştur. Göç eden bireylerde ne kentli ne de köylü kültürü bulunmaktadır. Bu kişiler ara kültüre sahiptir (Gürler ve ark., 2007).

Çizelge 3. Kentte yaşama süresi.

Table 3. Life time in the urban.

\begin{tabular}{lcccccc}
\hline Bireylerin kentte & \multicolumn{2}{c}{ Kadın } & \multicolumn{3}{c}{ Erkek } & \multicolumn{2}{c}{ Toplam } \\
\cline { 2 - 7 } yaşama süresi (Yıl) & $\mathbf{N}$ & \% & $\mathbf{N}$ & \% & N & \% \\
\hline 1 yıldan az & 2 & 1.1 & 6 & 2.8 & 8 & 1.99 \\
1-5 yıl arası & 23 & 12.2 & 50 & 23.4 & 73 & 18.16 \\
6-10 yıl arası & 37 & 19.7 & 51 & 23.8 & 88 & 21.89 \\
$11-20$ yıl arası & 116 & 61.7 & 74 & 34.6 & 190 & 47.26 \\
21 yıldan fazla & 10 & 5.3 & 33 & 15.4 & 43 & 10.70 \\
Toplam & 188 & 100.0 & 214 & 100.0 & 402 & 100.00 \\
\hline
\end{tabular}

Araştırmaya katılan bireylerden kadınların \%61.7'si 11-20 yıl arası süreden beri kentte yaşamakta iken, \%19.7'si 6-10 yıl, \%12.2'si 1-5 yıl, \%5.3'ü 21 yıldan fazla ve \%1.1'i 1 yıldan az süreden beri kentte yaşadığı tespit edilmiştir. Erkeklerin ise \%34.6'sının 11-20 yıl arası süreden beri kentte yaşamakta iken, \%23.8'inin 6-10 yıl, \%23.4'ünün 1-5 yıl, \%15.4'ünün 21 yıldan fazla ve \%2.8'inin 1 yıldan az süreden beri kentte yaşadığı görülmektedir. Araştırma kapsamındaki ailelerin büyük çoğunluğunun kentte yaşama sürelerinin köyde yaşama sürelerinden daha da fazla olduğu söylenebilir. Erkeklerin kadınlara göre kente daha önce geldikleri kendilerinin düzenini sağladıktan sonra eşlerini yanlarına aldıkları yönünde yorumlanabilir.

Çizelge 4. Ailelerin köyden ilk olarak göç ettikleri yer.

Table 4. The place where families first migrated from the village.

\begin{tabular}{lcccccc}
\hline \multirow{2}{*}{$\begin{array}{l}\text { Köyden ilk olarak göç edilen } \\
\text { yer }\end{array}$} & \multicolumn{2}{c}{ Kadın } & \multicolumn{3}{c}{ Erkek } & \multicolumn{2}{c}{ Toplam } \\
\cline { 2 - 7 } & $\mathbf{N}$ & \% & $\mathbf{N}$ & \% & $\mathbf{N}$ & \% \\
\hline Tokat merkeze & 166 & 88.4 & 173 & 80.9 & 339 & 84.32 \\
İlçe merkezine & 10 & 5.3 & 17 & 7.9 & 27 & 6.72 \\
Beldeye & 4 & 2.1 & 6 & 2.8 & 10 & 2.49 \\
Başka bir köye & 1 & 0.5 & - & - & 1 & 0.25 \\
Büyükşehre (Ankara,istanbul & 7 & 3.7 & 18 & 8.4 & 25 & 6.22 \\
vb) & 188 & 100.0 & 214 & 100.0 & 402 & 100.00 \\
Toplam & & & & &
\end{tabular}

Araşıırmaya katılan ailelerden kadınların \%88.4'ü köyden ilk olarak Tokat merkeze, \%5.3'ü ilçe merkezine, \%3.7'si büyük şehre, \%2.1'i beldeye ve \%0.5'i başka bir köye göç etmiştir. Erkeklerin ise \%80.9'u köyden ilk olarak Tokat merkeze, \%8.4'ü büyük şehre, \%7.9'u ilçe merkezine ve \%2.8'i beldeye göç etmiştir. Araştırmadan ailelerin büyük çoğunluğunun köyden ilk olarak şehir merkezine göç ettikleri sonucu çıkmaktadır.

Ailelerin köyden ilk olarak göç ettikleri yere yaş gruplarına göre bakıldığında 23-30 ve 39-46 yaş grubunun öncelikle ilçe merkezi, 31-38 yaş grubunun belde, 47-54 ve 55-63 yaş grubundakilerin ise Tokat Merkez'e göç ettikleri görülmektedir. 
Çizelge 5. Ailelerin köyden ilk olarak göç ettikleri yerin yaş gruplarına göre dağılımı Table 5. Distribution by age group of the place where families first migrated from the village

\begin{tabular}{|c|c|c|c|c|c|c|c|c|c|c|c|c|}
\hline \multirow{3}{*}{ Yaş grupları } & \multicolumn{12}{|c|}{ Bireylerin köyden ilk olarak göç ettikleri yer } \\
\hline & \multicolumn{2}{|c|}{ Tokat merkez } & \multicolumn{2}{|c|}{ ìlçe merkezi } & \multicolumn{2}{|c|}{ Belde } & \multicolumn{2}{|c|}{$\begin{array}{c}\text { Başka bir } \\
\text { köy }\end{array}$} & \multicolumn{2}{|c|}{ Büyük şehir } & \multicolumn{2}{|c|}{ Toplam } \\
\hline & $\mathbf{N}$ & $\%$ & $\mathbf{N}$ & $\%$ & $\mathbf{N}$ & $\%$ & $\mathbf{N}$ & $\%$ & $\mathbf{N}$ & $\%$ & $\mathbf{N}$ & $\%$ \\
\hline $23-30$ & 26 & 7.7 & 6 & 22.2 & 2 & 20.0 & - & - & 1 & 4.0 & 35 & 8.71 \\
\hline $31-38$ & 87 & 25.7 & 8 & 29.6 & 5 & 50.0 & 1 & 100.0 & 4 & 16.0 & 105 & 26.12 \\
\hline $39-46$ & 98 & 28.9 & 8 & 29.6 & 2 & 20.0 & - & - & 9 & 36.0 & 117 & 29.10 \\
\hline $47-54$ & 87 & 25.7 & 4 & 14.9 & 1 & 10.0 & - & - & 7 & 28.0 & 99 & 24.63 \\
\hline $55-63$ & 41 & 12.0 & 1 & 3.7 & - & - & - & - & 4 & 16.0 & 46 & 11.44 \\
\hline Toplam & 339 & 100.0 & 27 & 100.0 & 10 & 100.0 & 1 & 100.0 & 25 & 100.0 & 402 & 100.00 \\
\hline
\end{tabular}

Çizelge 6. Kente göç etme nedenleri.

Table 6. Reasons to migrate to the urban.

\begin{tabular}{|c|c|c|c|c|c|c|}
\hline \multirow[t]{2}{*}{ Nedenler } & \multicolumn{2}{|c|}{ Kadın } & \multicolumn{2}{|c|}{ Erkek } & \multicolumn{2}{|c|}{ Toplam } \\
\hline & $\mathbf{N}$ & $\%$ & $\mathbf{N}$ & $\%$ & $\mathbf{N}$ & $\%$ \\
\hline İş bulmak & 109 & 58.0 & 109 & 50.9 & 218 & 54.23 \\
\hline Eğitim almak & 40 & 21.3 & 58 & 27.1 & 98 & 24.38 \\
\hline \multicolumn{7}{|l|}{ Şehirde yaşayan } \\
\hline akrabalarına yakın olmak & 11 & 5.9 & 11 & 5.1 & 22 & 5.47 \\
\hline Zengin olmak & - & - & 7 & 3.3 & 7 & 1.74 \\
\hline Sağlıktan yararlanmak & 3 & 1.6 & 9 & 4.2 & 12 & 2.98 \\
\hline $\begin{array}{l}\text { Töreler (kan davası, namus } \\
\text { davası vb.) }\end{array}$ & - & - & 2 & 0.9 & 2 & 0.5 \\
\hline $\begin{array}{l}\text { Diğer (Daha iyi bir yaşam, } \\
\text { evlilik, iklimini sevdiğinden, } \\
\text { görevi, işi, nakil) }\end{array}$ & 25 & 13.2 & 18 & 8.5 & 43 & 10.70 \\
\hline Toplam & 188 & 100.0 & 214 & 100.0 & 402 & 100.00 \\
\hline
\end{tabular}

Araştırmaya katılan ailelerden kadınların kente göç etme nedenleri arasında birinci sırada \%58.0 oran ile iş bulmak, ikinci sırada \%21.3 oranla eğitim olanaklarından yararlanmak yer almaktadır. Erkeklerin ise kente göç etme nedenleri arasında birinci sırada \%50.9 oran ile iş bulmak, ikinci sırada \%27.1 ile eğitim olanaklarından yararlanmak yer almaktadır.

\section{Ailelerin Kız Çocuklarına Yönelik Tutum ve Davranışlarına ilişkin Yargılar}

Aile kurumunun sürekli gelişim ve değişim sürecine bağlı olarak çocuklarını yetiştirme ve çocuklarıyla arasındaki ilişkilerde geçmişten günümüze farklılık bulunmaktadır. Ailenin temel sorumluluğu çocuklarını iyi yetiştirmeye çaba göstererek topluma kazandırmaktır. Ailelerin bu sorumluklarının temeli ise iyi çocuk yetiştirmeye dair olumlu davranışlar geliştirmeleridir (Şahin ve Cevher, 2007).

Çocuğun gelişiminde annenin önemi yadsınamaz. Ancak babanın rolü bu gelişimi tamamlayıcılık rolü üstlenir. Baba ve anneyle kurulan iyi ilişkiler çocuğun gelişimini fiziksel ve psikolojik anlamda korumakta ve geliştirmektedir. Anne ve babalarıyla tatminkâr bir ilişkiyi sahiplenerek büyüyen kız çocukları gelecekte kendine güvenen, uygun eş seçimleri yapan, yakın ilişkiler kurabilen, duygusal ve psikolojik açıdan sağlıklı tepkiler verebilen, mantıkıı ilişkiler kurabilen kadınlar olacaklardır.

Kadınla erkeğin aile içindeki rollerinde, aile içi iletişimde ve çocuğun yetiştirilme tarzında; eğitim düzeyindeki artış, daha çok kadının iş hayatına yönelmesi, televizyon, internet, sosyal medya araçlarının yayılım göstererek yoğun şekilde izleniyor olmasının insanların tutumlarında ortaya çıkardığı yansımalar değişiklik yaratabilmektedir.

Ailelerin kız çocuklarına yönelik yargı ve düşünceleri Çizelge 7'de verilmiştir.

Araştırmada ailelerin kız çocuklarına ilişkin algıları genel olarak değerlendirildiğinde bakış açısı olarak demokratik ve kız çocuklarının güçlendirilmesi gereği yönündedir. Aileler kız çocuklarının toplumsal cinsiyet algısına göre farklı bir kategoride olmamaları yönünde algıya sahip görülmektedir. Kız çocuklarının toplum içinde güçlü olmaları için eğitim almaları, çalışmaları, ekonomik özgürlüğe sahip olmaları, yasal ve sosyal haklardan eşit şekilde yararlanmaları, cinsiyet ayrımı gözetmeksizin tüm faaliyetler içerisinde yer almaları konusunda düşünce yapısına sahip oldukları belirlenmiştir. 
Çizelge 7. Kız çocuklarına yönelik yargı ve düşünceler.

Table 7. Thoughts and judgments towards daughters.

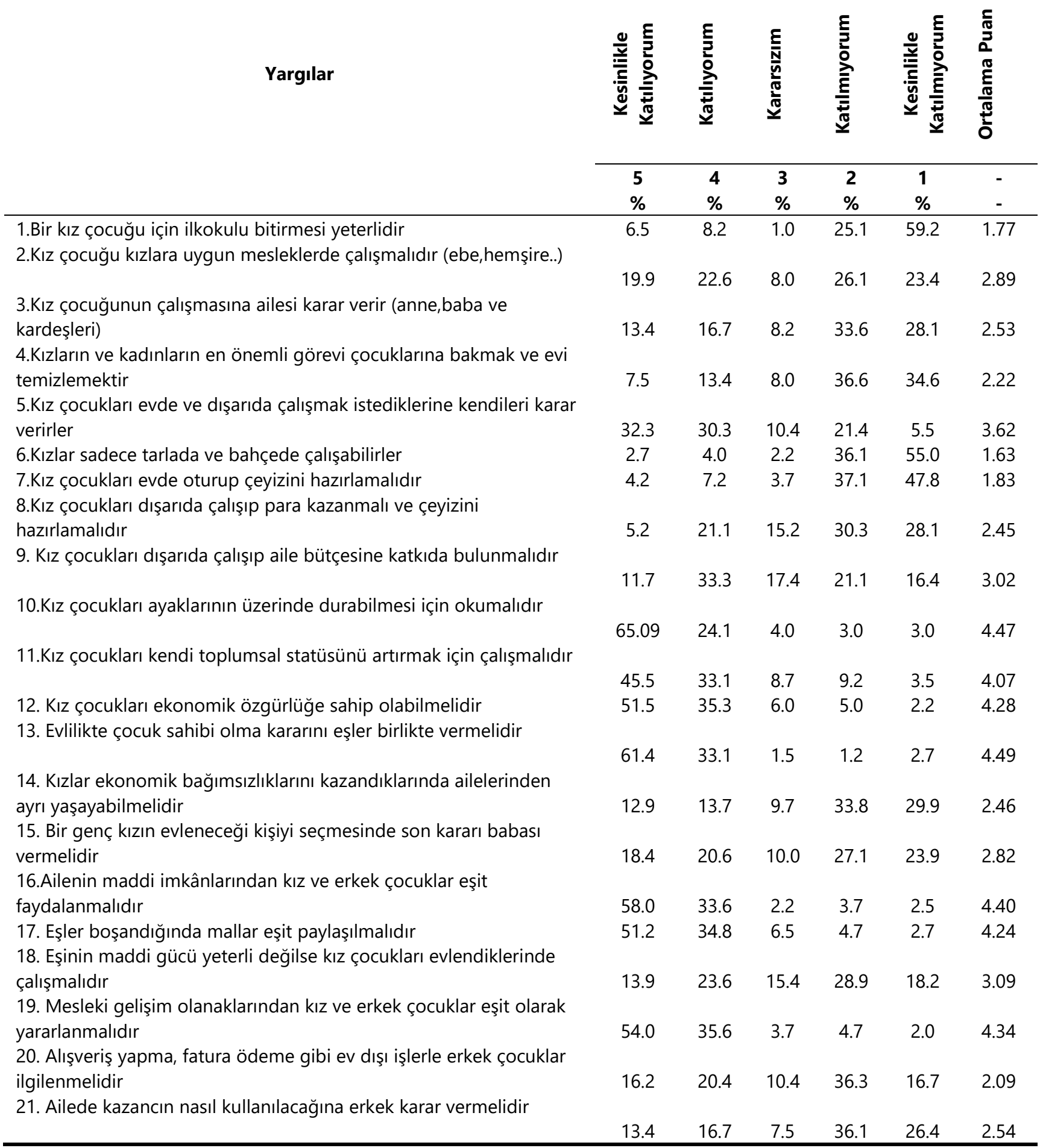

Tokat ilinde yapılan bir araştırmada kırdan kente göç eden kadınların \%79.25'i kız çocuklarının okumasını istediklerini bunun nedenini de en fazla gelecekte kızlarının sosyal statüsünün artması için (\%98.11) istediklerini belirtmişlerdir (Kızılaslan, 2013).

Kırsal alanda kadınlara yönelik toplumsal cinsiyet algısını belirlemek amacıyla yürütülen bir araştırmada, kadının çalışma hayatı ile ilgili önermeler genel olarak incelendiğinde, kırsal alanda yaşayan kadınlar, kadınların çalışma hayatına girmesine erkeklere nazaran daha sıcak bakmaktadır. Kırsal alanda yaşayan kadınlar kadınların ticaret yapmalarına, kadınların yönetici pozisyonunda olabileceklerine, evlendikten sonra da çalışmalarına, kadınların çalışma hayatının ev işlerini aksatmayacağına ve anne olduktan sonra da çalışabileceklerine erkeklere nazaran daha fazla inanmaktadır. Erkeklerin ise daha geleneksel bir tutum içinde oldukları ailenin gelirinin erkekler tarafından sağlaması gerektiği ve kadının kocasından fazla para kazanmaması gerektiği görüşündedir (Çukur ve 
ark., 2020). Başka bir çalışmada, toplumsal cinsiyet rollerine kadınların erkeklere göre daha eşitlikçi, daha demokratik ve daha aktif bakış açısıyla değerlendirdikleri görülmüştür (Kızılaslan ve Yamanoğlu, 2010).

Toplumsal cinsiyet konusunda bilinçli bir toplum haline gelmek gerekmektedir. Kadını güçlendirmek, çevresini ve olayları değiştirebilecek bir pozisyona getirmekle söz konusudur. Yaşamını yönlendirme gücü, yaşamı ile ilgili seçeneklere sahip olma, fırsat ve kaynaklara erişme, kendine güven ve saygı bu pozisyonlardan bazılarıdır. Eğitim, iş geliştirme, liderlik, eşit fırsat, sağlık, güvenlik, şiddet görmeme, toplumsal katılım, şeffaf anlayış, krediye erişim kadının güçlendirilmesinde içinde bulunulması gereken işleyişi ifade eder. Bu işleyişteki iyileşme bir başlangıç olup toplumun sosyal ve kültürel yapısında da kadına bakış açısının iyileşme yönünde değişmesi gerekir (Kızılaslan ve Kızılaslan, 2020).

Bu araştırmada geleneksel düşünce olan kız çocuklarının evdeki işlerle ilgilenmesi, eğitiminin belli seviyede durdurulması, kısa sürede evlendirilmesi, belli meslek dallarında çalışması ya da hiç çalışmaması gibi düşüncelere olumsuz bakmaktadırlar. Kız çocuklarının çalışmasında ailenin kararı, kızlara uygun meslek seçimi, aile bütçesine katkı, aile bütçesinin paylaşımındaki karar, evlilik kararında aile rolü gibi konulardaki algılar kararsızlık noktasında bulunmaktadır.

Tokat'ta yapılan bir çalışmada kadınların aile içi kararlarda göç öncesinde \%11.83 tek başına etkinliği söz konusu iken göç sonrasında bunun \%38.46'ya çıkı̆̆ı görülmektedir. Burada aile yapısının çekirdek aile yapısına dönüşümünün ve demokratikleşme eğilimlerinin artmasıyla bağlantı kurulmuştur (Kızılaslan, 2013).

Genel olarak değerlendirildiğinde kırdan kente göç eden ailelerin kız çocuklarına yönelik geleneksel düşüncelerden arındığı, onların okumaları ve çalışmalarını önemsediği, kız ve erkek çocukları arasında ayrım yapmak istemedikleri cinsiyet eşitsizliğine karşı oldukları sonucu ortaya çıkmaktadır. Bu bulgular sosyal değişimin de etkisiyle kentte gördükleri farklı norm ve kalıplara göre şekillenmiş algılar olarak düşünülebilir.

\section{Ailelerin Kız Çocuklarına Yönelik Tutum ve Davranışlarına ilişsin Faktör Analizi Sonuçları}

Ailelerin kız çocuklarına yönelik tutum ve davranışlarını ölçmeye yönelik olarak 21 yargı cümlesinin belli faktör değerlerinde birleşip birleşmediğini test etmek amacıyla faktör analizi yapılmıştır. Bu analiz ile ailelerin kız çocuklarıyla ilgili tutum ve davranışları hususundaki esas belirleyicileri ve bu belirlemede ağırlıkların tespit edilmesi planlanmıştır.

Araştırmada Kaiser-Meyer-Olkin (KMO) ölçümü, değişkenlerin faktör analizi için uygun olup olmadığını belirlemek amaçlı yapılmıştır. KMO için alt sınır değerinin 0.50 olması gerekmektedir. KMO test sonucu 0.877 olarak bulunmuştur. Ayrıca Bartlett's Test Of Sphericity değeri ve anlamlılığı değişkenlerin birbirleriyle korelasyon gösterip göstermediklerini açıklar ve kullanılan verilerle faktör analizi yapmanın uygunluğunu test eder $(p<0.05)$. Çizelge 8'de görüldüğü gibi çıkan her iki değerde değerlendirilen verilerin faktör analizi için uygun olduğunu göstermiştir.

Çizelge 8. Faktör analizine uygunluk testi sonuçları.

Table 8. Results compliance test for factor analysis.

\begin{tabular}{lll}
\hline Kaiser-Meyer-Olkin Örneklem Yeterliliği Ölçüsü & .877 \\
\hline \multirow{3}{*}{ Bartlett's Küresellik Testi } & Approx. Chi-Square & 3785.794 \\
& df & 210 \\
& Sig. & 0.000 \\
\hline
\end{tabular}

Faktör analizinin başlangıç analizinde faktör sayısına karar vermek için kullanılan özdeğerler, varyans ve birikimli varyans değerleri hesaplanmıştır ve Tablo 9'da verilmiştir. Özdeğerleri 1'den büyük olan faktör sayısı 5'tir. Bu 5 faktörün tümü toplam varyansın \%63.633'ünü açıklamaktadır.

Çizelge 9. Faktör analizi başlangıç çözüm istatistik sonuçları Table 9. Initial resolution statistics results on factor analysis

\begin{tabular}{cccc}
\hline Faktör no & Öz değer & Varyans açıklama oranı & Birikimli varyans \\
\hline $\mathbf{1}$ & 6.757 & 32.176 & 32.176 \\
$\mathbf{2}$ & 2.698 & 12.849 & 45.025 \\
$\mathbf{3}$ & 1.709 & 8.136 & 53.162 \\
$\mathbf{4}$ & 1.172 & 5.580 & 58.742 \\
$\mathbf{5}$ & 1.027 & 4.891 & 63.633 \\
\hline
\end{tabular}

Faktör analizi sonuçlarına göre oluşan 5 faktör Çizelge 10'da görülen bileşenlerden oluşmaktadır. Bu 5 faktör; faktör yükü 0.5 ve üzeri olan bileşenler dikkate alınarak isimlendirilmiştir. 
Araşıırmada, faktör yapısının incelenmesinde yaygın olan Temel Bileşenler Analizi (Princpal Components Analysis) Equamax rotasyon yöntemiyle birlikte kullanılmıştır. Bu yöntemle faktörlerin hangi değişkenlerden oluştuğu belirlenmiştir. Faktör analizinin başlangıç çözümünde faktör sayısını karar vermede kullanılan öz değerler, varyans ve birikimli varyans değerleri hesaplanmıştır. Bu hesaplamalara göre, öz değeri 1'den büyük olan faktörler seçilmiştir. Buna bağlı olarak Equamax rotasyon çözümüne göre faktörler isimlendirilmiş ve değişkenler yorumlanmıştır.

Çizelge 10. Faktör analizi sonuçları.

Table 10. Results on factor analysis.

\begin{tabular}{|c|c|c|}
\hline Faktörler ve Faktörü Oluşturan Değişkenler & Faktör Yükü & Açıklama Oranı (\%) \\
\hline Faktör 1: Kız Çocuklarının Aile İçindeki Konumu & & 32.176 \\
\hline
\end{tabular}

Bir kız çocuğu için ilkokulu bitirmesi yeterlidir

0.759

Kız çocuklarının çalışmasına ailesi karar verir (anne, baba ve

kardeşleri)

0.724

Kızların ve kadınların en önemli görevi çocuklarına bakmak ve evi

temizlemektir.

Kız çocuğu kızlara uygun mesleklerde çalışmalıdır (ebe, hemşire) $\quad 0.687$

Kız çocukları evde oturup çeyizini hazırlamalıdır

0.686

Alışveriş yapma, fatura ödeme gibi ev dışı işlerle erkek çocuklar

ilgilenmelidir

0.682

Kızlar sadece tarlada ve bahçede çalışabilirler

0.673

0.650

Ailede kazancın nasıl kullanılacağına erkek karar vermelidir

0.542 vermelidir

\begin{tabular}{|c|c|c|}
\hline Faktör 2: Kız Çocuklarının Çalışmasında Ailenin Rolü & & 12.849 \\
\hline Kız çocukları ayaklarının üzerinde durabilmesi için okumalıdır & 0.787 & \\
\hline Kız çocukları ekonomik özgürlüğe sahip olabilmelidir & 0.779 & \\
\hline Kız çocukları kendi toplumsal statüsünü artırmak için çalışmalıdır & 0.743 & \\
\hline Evlilikte çocuk sahibi olma kararını eşler birlikte vermelidir & 0.724 & \\
\hline Faktör 3: Ailenin Cinsiyet Eşitliğine Tutumu & & 8.136 \\
\hline Eşler boşandığında mallar eşit paylaşılmalıdır & 0.804 & \\
\hline $\begin{array}{l}\text { Mesleki gelişim olanaklarından kız ve erkek çocuklar eşit } \\
\text { yararlanmalıdır }\end{array}$ & 0.799 & \\
\hline $\begin{array}{l}\text { Ailenin maddi imkânlarından kız ve erkek çocuklar eşit } \\
\text { faydalanmalıdır }\end{array}$ & 0.782 & \\
\hline Faktör 4: Kişisel Kararlarda Özgürlük & & 5.580 \\
\hline $\begin{array}{l}\text { Kızlar ekonomik bağımsızlıklarını kazandıklarında ailelerinden ayrı } \\
\text { yaşayabilmelidir }\end{array}$ & 0.668 & \\
\hline $\begin{array}{l}\text { Kız çocukları evde ve dışarda çalışmak istediklerine kendileri karar } \\
\text { verirler }\end{array}$ & 0.585 & \\
\hline $\begin{array}{l}\text { Eşinin maddi gücü yeterli değilse kız çocukları evlendiklerinde } \\
\text { çalışmalıdır }\end{array}$ & 0.574 & \\
\hline Faktör 5: Kız Çocuklarının Aile Bütçesine Katkısı & & 4.891 \\
\hline Kız çocukları dışarda çalışıp aile bütçesine katkıda bulunmalıdır & 0.858 & \\
\hline $\begin{array}{l}\text { Kız çocukları dışarda çalışıp para kazanmalı ve çeyizini } \\
\text { hazırlamalıdır }\end{array}$ & 0.804 & \\
\hline
\end{tabular}

Kız çocuklarının çalışması ve sorumlulukları ile ilgili ilk faktör "kız çocuklarının aile içindeki konumu" olarak saptanmış ve Faktör 1 şeklinde isimlendirilmiştir. Bu faktör varyansın \%32.176'sını açıklamaktadır. Faktör 1, bir kız çocuğu için ilkokulu bitirmesi yeterlidir, kız çocuklarının çalışmasına ailesi karar verir (anne, baba ve kardeşleri), kızların ve kadınların en önemli görevi çocuklarına bakmak ve evi temizlemektir, kız çocuğu kızlara uygun mesleklerde çalışmalıdır (ebe, hemşire). Kız çocukları evde oturup çeyizini hazırlamalıdır; alışveriş yapma, fatura ödeme gibi ev dışı işlerle erkek çocuklar ilgilenmelidir, kızlar sadece tarlada ve bahçede çalışabilirler, ailede kazancın nasıl kullanılacağına erkek karar vermelidir, bir genç kızın evleneceği kişiyi seçmesinde son kararı babası vermelidir bileşenlerini içermektedir. Kız çocuklarının okumasına bağlı olarak kendini geliştirmesi demek o ülkenin eğitim ve kültür seviyelerinin yükselmesi anlamına gelir. Çünkü toplumun eğitim seviyesi ile kültürel birikimi, dünya üzerinde statüsünü belirler. Zorunlu eğitim çağındaki kız çocuklarının okula gönderilmemesi veya çalışma olanaklarının kısıtlandıııması demek bireysel hak ve özgürlüklerinin sınırlandırılması anlamına gelir. Her çocuğun 
doğuştan kazandığı doğal yaşam haklarından cinsiyet ayrımı gözetilmeksizin kız çocukları da eşit faydalandırılmalıdır.

"Kız çocuklarının çalışmasında ailenin rolü" Faktör 2'de isimlendirilmiştir. Bu faktör varyansın \%12.849'unu açıklamaktadır. Kız çocukları ayaklarının üzerinde durabilmesi için okumalıdır, kız çocukları ekonomik özgürlüğe sahip olabilmelidir, kız çocukları kendi toplumsal statüsünü artırmak için çalışmalıdır, evlilikte çocuk sahibi olma kararını eşler birlikte vermelidir bu faktörün bileşenleridir. Kız çocuğuna çalışma imkânı vermek, ona yeteneklerini geliştirme olanağı tanımak toplumsal gelişmenin de sürekliliğini sağlamak demektir. Evlilikte ortak kararlar almak mutlu ve uzun ömürlü evliliklerin sırları arasındadır.

"Ailenin cinsiyet eşitliğine tutumu" Faktör 3'te isimlendirilmiştir. Bu faktör varyansın \%8.136'sını açıklamaktadır. Eşler boşandığında mallar eşit paylaşılmalıdır, mesleki gelişim olanaklarından kız ve erkek çocuklar eşit yararlanmalıdır, ailenin maddi imkânlarından kız ve erkek çocuklar eşit faydalanmalıdır bu faktörün bileşenleridir. Aile içerisinde kız ve erkek çocuklarına eşit gösterilen muamele, eşit fırsatların tanınması eşitlik ilkesinin oluşmasına yardımcı olur. Anne ve babaların çocuklarını yetiştirirken çocukların cinsiyetlerine bakılarak değil, kişsisel farklılıklarına göre muamele edilmesi, cinsiyetin gerektirdiği rolleri çocuğa yüklenmemesi ve ikisinin de eşit hak ve koşullara sahip olduğu gerçeği unutulmamalıdır.

"Kişisel kararlarda özgürlük" Faktör 4'te isimlendirilmiştir. Bu faktör varyansın \%5.580'ini açıklamaktadır. Kızlar ekonomik bağımsızlıklarını kazandıklarında ailelerinden ayrı yaşayabilmelidir, kız çocukları evde ve dışarda çalışmak istediklerine kendileri karar verirler, eşinin maddi gücü yeterli değilse kız çocukları evlendiklerinde çalışmalıdır bu faktörde ağır basmaktadır. Kız çocukları aile içindeki görevlerinin beraberinde toplumda birey olmanın getirdiği sorumlulukla kendilerini sadece eve ait olduklarını hissetmeyip çalışma hayatına da girmişledir. Bu hakların kız çocuklarına tanınması, ailenin bu konudaki tutumu kız çocuklarının kişisel kararlarında özgür bırakılması açısından önemlidir.

"Kız çocuklarının aile bütçesine katkısı" Faktör 5'te isimlendirilmiştir. Bu faktör varyansın \%4.891'ini açıklamaktadır. Kız çocukları dışarda çalışıp aile bütçesine katkıda bulunmalıdır, kız çocukları dışarda çalışıp para kazanmalı ve çeyizini hazırlamalıdır yargıları bu faktörde ağır basmaktadır. Kız çocuklarının çalışması demek bir anlamda ailesini de ekonomik anlamda kalkındırmak, katkı sağlamak ve bireysel anlamda kendi ihtiyaçlarını da karşılaması anlamına gelir. Aynı zamanda aile yapısında meydana gelen değişmeler bütçe olanakları doğrultusunda tüketici davranışları ve kalıplarında da değişimlere neden olmakta, sağlıklı ve yeterli beslenme alışkanlıklarının kazanılmasında önemli faktörleri tetikleyen bir profil de ortaya çıkarmaktadır (Kızılaslan, Göktolga ve Kızılaslan, 2008; Kızıloğlu, Kızılaslan ve Dölek, 2013; Kızılaslan ve Nalinci, 2013; Onurlubaş, Yılmaz, Doğan ve Kızılaslan, 2015; Kızılaslan ve Nalinci, 2013; Kızılaslan, 2019).

\section{SONUÇ}

Kız çocuklarının toplumsal statülerinin geliştirilmesi, eğitim ve istihdam şartlarında eşit imkânlara sahip olmaları, toplumların sosyal ve ekonomik kalkınmalarında önemli rol oynamaktadır.

Bu araştırmada, ailelerin kız çocuklarının eğitimleri ve çalışmaları konusunda genel olarak olumlu tutum içinde oldukları, kız çocuklarının evlilik şekillerinde kısmen de olsa gelenekselliğin devam ettiği ve kente uyum sağladıkları ortaya çıkmıştır. Toplumsal cinsiyet rollerine ilişkin düşünce farklılıklarının kısmen de olsa devam ettiği ancak demokratik düşünce kalıplarının şekillendiği görülmüştür. Kız çocuklarının güçlendirilmesi noktasında kararlıı̆ın olduğu görülmüştür. Toplumsal cinsiyet rollerine özgü algı ve davranışlarda olumlu değişimlerin sağlanması kız çocuklarının toplum içerisindeki yeri ve konumunda da olumlu yansımalar meydana getirecektir. Toplumun bakış açısı sosyal değişim sürecinde pozitif yönde bir eğilim gösterecektir. Bu süreçte uygulanacak politikalar toplumsal cinsiyet rolleri algısının kız çocukları lehinde değişimi ve gelişimini de beraberinde getirecektir. Zaten özellikle kentsel toplumlarda kırılmaya başlayan kız çocukları ve kadınlara yönelik toplumsal cinsiyet rollerine ilişkin olumsuz tutumlamaların kırsal toplumlarda da sosyal değişim sürecinde aynı etkiyi göstereceği söylenebilir. Bu etkinin hızlandırılması için örgün eğitim döneminde zorunlu eğitime gönderilemeyen veya zorunlu eğitimi tamamlamadan okullarından ayrılan kız çocukları belirlenerek ailelerle iletişime geçilmeli, aileleri ikna ederek gereken önlemler alınmalıdır. Kız çocuklarına yönelik yapılacak araştırmalarla çalışan ve çalışmayan kız çocuklarının sosyal konumları, aralarındaki farklılıklar ve kız çocuklarının aldıkları eğitimin toplumsal hayattaki önemi ortaya konulmalı, iletişim araçları ile topluma bilgi verilmelidir. Geleneksel düşünce ve değer yargılarının etkisinin azaltılması için eylem planları hazırlanarak uygulamaya geçirilmeli sürdürülebilirliği sağlanmalıdır. 


\section{ÇIKAR ÇATIŞMASI}

Yazarlar arasında herhangi bir çıkar çatışması bulunmamaktadır.

\section{YAZAR KATKISI}

Makalenin konu dizaynı, yöntem, yazımı, istatistiksel analiz ve yorumları E.S. tarafından yapılmıştır. Yönlendirme, kontrol ve düzeltmeler N.K. tarafından yapılmıştır.

\section{KAYNAKLAR}

Anonim. (2019). Tokat Belediyesi Kayttları. Tokat.

Arpacı, F., \& Tokyürek, Ş. (2008). Kırdan kente göç eden ailelerde bireylerin kız çocuklarının meslek kazanması ve çalışmasına ilişkin görüşleri. E-journal of New World Sciences Academy, 3(1), 54-65.

Çukur, T., Kızılaslan, N., Kızılaslan, H., \& Çukur, F. (2020). Gender perception towards women in rural areas in Turkey, rural environment, education, personality. Proceedings of the 13th International Scientific Conference, Jelgava, Latvia.

Ekici, S., \& Tuncel, G. (2015). Göç ve insan. Birey ve Toplum Sosyal Bilimler Dergisi, 5(9), 9-22.

Erkan, R. (2010). Kentleşme ve Sosyal Değişme. Bilimadamı Yayıncılık, Ankara.

Geyik, S. (2010). Kırdan kente gö̧̧ sonrası kentlilik bilinci (Mevlana Mahallesi örneği). Yüksek Lisans Tezi, Sakarya Üniversitesi, Sosyoloji Anabilim Dalı, Sakarya.

Günay, E., Atılgan, D., \& Serin, E. (2017). Dünya'da ve Türkiye'de göç yönetimi. Kahramanmaraş Sütçü Imam Üniversitesi Iiktisadi ve İari Bilimler Fakültesi Dergisi, 7(2), 37-60.

Gürler, A. Z., Kızılaslan, N., Kızılaslan, H., \& Doğan, S. (2007). Rural-urban migration in Turkey and the socio-economic characteristics of the Immigrants (Tokat Case). Research Journal of Social Sciences, 2, 60-71.

Hatipoğlu, F. (2008). Kentleşmenin çocuk suçluluğuna etkisi ve bir çözüm önerisi denemesi. Yüksek Lisans Tezi, Gazi Üniversitesi, Kamu Yönetimi Anabilim Dalı, Ankara.

Karagöz, Y., \& Kösterelioğlu, í. (2008). Iletişim becerileri değerlendirme ölçeğinin faktör analizi metodu ile geliştirilmesi. Dumlupınar Üniversitesi Sosyal Bilimler Dergisi, 21, 81-97.

Karakuş, E. (2006). Göç olgusu ve eğitime olumsuz etkileri (Sultanbeyli örneği). Yüksek Lisans Tezi, Sakarya Üniversitesi. Sosyal Bilimler Enstitüsü, Sakarya.

Kızılaslan, H., Gökalp, Z., \& Kızılaslan, N. (2008). An analysis of the factors affecting the food places where consumers purchase red meat. British Food Journal, 110, 580-594.

Kızılaslan, H., \& Nalinci, S. (2013). Amasya ili merkez ilçedeki hanehalkının kanatı eti tüketim alışkanlıkları ve kanatlı eti tüketimini etkileyen faktörler. Gaziosmanpaşa Bilimsel Araştırma Dergisi, 6, 1-18.

Kızılaslan, H., \& Nalinci, S. (2013). Amasya ili merkez ilçedeki hane halkının balık eti tüketim alışkanlıkları ve balık eti tüketimini etkileyen faktörler. Gaziosmanpaşa Bilimsel Araştırma Dergisi, 5, 61-75.

Kızılaslan, N. (2016). Ailenin sosyo-ekonomik düzeyinin çocuğun beslenmesine ve ağırlık yönetimine etkisi. Gaziosmanpaşa Bilimsel Araştırma Dergisi, 12, 25-30.

Kızılaslan, N. (2006). Kente uzaklı̆ıın kırsal aile yapısına etkileri, Zonguldak Karaelmas Üniversitesi Sosyal Bilimler Dergisi, 2(3), $141-162$.

Kızılaslan, N., \& Yamanoğlu, A. (2010). Social gender analysis in a turkish province. the province of Tokat: a case study, New Mediterranean Journal of Economics, Agriculture and Environment, 9(3), 76-80.

Kızılaslan, N., (2013). Kırdan Kente Göç Olgusunda Kadının Rolü ve Göç Kararındaki Etkisinin Analizi (Tokat ili Örneği). Gaziosmanpaşa Üniversitesi Ziraat Fakültesi, Yayın No:75, Araştırma Serisi No:27, Tokat.

Kızılaslan, N. (2016). Türkiye'de Kırsal kalkınma perspektifinde kadın. Kırsal Kalkınma Dergisi, 4, 30-39,

Kızılaslan, N., Kızılaslan, H., \& Kurt, E. (2017). Kırdan kente göç etmiş kadınların kentten yararlanma düzeylerinin incelenmesi: Tokat ili Merkez ilçe örneği. International Balkan and Near Eastern Social Sciences Congress Series III. IBANESS Congress Series, Edirne, Turkey.

Kızılaslan, N. (2019). An analysis of factors affecting fish consumption in a healthy and balanced nutrition. Asian Journal of Clinical Nutrition, 17(1), 9-16. 
Kızılaslan, N., \& Kızılaslan, H. (2020). Problems and strategic recommendations for empowerment of women in Turkey. Sosyal Bilimler Araştırmaları Dergisi, Özel Sayı I/II, 46-51.

Kızıloğlu, R., Kızılaslan, H., \& Dölek, G., (2013). Ekolojik yumurta ile endüstriyel yumurta tüketim tercihlerinin belirlenmesi üzerine bir araştırma: Tokat ili Merkez örneği. Alınteri, 24(1),20-28.

Onurlubaş, E., Yılmaz, N., Doğan, H. G., \& Kızılaslan, H. (2015). A research on red meat consumption and preferences: a case study in Tekirdağ province. Turkish Journal of Agriculture-Food Science and Technology, 3(6), 466-471.

Pala, A. (2013). Zorunlu göç ve kadın deneyimi: Diyarbakır örneği. Yüksek Lisans Tezi, Hacettepe Üniversitesi. Antropoloji Anabilim Dalı, Ankara.

Şahin, T., \& Cevher, F. N., (2007). Türk toplumunda aile-çocuk ilişkilerine genel bir bakış. 38. Uluslararası Asya ve Kuzey Afrika Çalışmaları Kongresi, Atatürk Kültür, Dil ve Tarih Yüksek Kurumu, Ankara.

Şahin, Y., (2010). Kentleşme Politikası. Karadeniz Teknik Üniversitesi, İktisadi ve İdari Bilimler Fakültesi, Murathan Yayıncılık, Trabzon.

Tümtaş, S., \& Ergun, C. (2016). Göçün toplumsal ve mekansal yapı üzerindeki etkileri. Süleyman Demirel Üniversitesi iktisadi ve idari Bilimler Fakültesi Dergisi, 21(4), 1347-1359. 